\title{
SIKAP ORMAS-ORMAS ISLAM LOKAL DI PAMEKASAN TERHADAP RADIKALISME AGAMA
}

\author{
Ibnu Ali \& Mujiburrahman \\ Universitas Islam Madura \\ ibnualialfarabi@gmail.com
}

\begin{abstract}
ABSTRAK
Term radikalisme agama merupakan pembahasan yang sensitif dan dinilai berpotensi mendiskreditkan kelompok tertentu. Di kalangan pemikir belum ada kesepatan terminologis tentang radikalisme agama. Penelitian ini bertujuan mencari tahu bagaimana sikap ormas-ormas Islam lokal di Pamekasan terhadap radikalisme agama. Peneliti memfokuskan objek penelitian pada ormas-ormas Islam lokal di Pamekasan yaitu NU, Muhammadiyah, SI, Persis, Hidayatullah, dan FPI. Dengan metode kualitatif, data diambil melalui wawancara secara terstruktur terhadap sample yang diambil dari ormas, baik secara acak atau secara kolektif. Hasilnya, sikap ormas tersebut dapat dipahami dalam tiga komponen, yaitu kognitif, afektif, dan konasi. Secara kognitif, ormas-ormas tersebut memberikan pandangan yang berbeda-beda tentang term radikalisme agama. Ada yang mendefinisikan dengan jelas, baik secara luas maupun sempit. Ada yang tidak memberikan definisinya. Secara afektif, mayoritas menganggap persoalan ini sebagai isu dan stigma sehingga mayoritas mereka tidak setuju dengan term radikalisme agama. Dan secara konasi semua ormas Islam mengambil peran dalam menghadapi persoalan tersebut meski dengan intensitas yang berbeda.
\end{abstract}

Kata Kunci: Sikap ormas, radikalisme

\section{ABSRACT}

The term religious radicalism is a sensitive discussion and is considered to have the potential to discredit certain groups. There is no terminological agreement among thinkers about religious radicalism. This study aims to find out how the attitudes of local Islamic organizations in Pamekasan towards religious radicalism. Researchers focused on the object of research on local Islamic organizations in Pamekasan, namely NU, Muhammadiyah, SI (Syarikat Islam), Persis, Hidayatullah, and FPI. With a qualitative method, data were collected through structured interviews with samples taken from mass organizations, either randomly or collectively. The planned output is an accredited national journal, while the additional quotation is just books.As a result, the attitudes of these organizations can be understood in terms of three components, namely cognitive, affective, and conative. Cognitively, these mass organizations provide different views on the term religious radicalism. There are those who define it clearly, both broadly and narrowly. Some didn't give the definition. Affectively, the majority considered this issue as an issue and a stigma so that the majority of them did not agree with religious radicalism. And conventionally all Islamic mass organizations take a role in dealing with these problems even though with different intensities.

Keywords: the attitude of local Islamic organization, Radicalism 


\section{Pendahuluan}

Secara mendasar, Islam merupakan agama yang wasathan (pertengahan/moderat). Namun fakta sejarah telah memetakan umat Islamkedalam kelompok-kelompok yang berbeda pemikiran dan pandangan, bahkan sampai beda gerakan. Masing-masing menjustifikasi kelompoknya sebagai yang paling Islami, sementara kelompok yang lain kurang atau tidak Islami, bahkan diantaranya ada yang sampai mentakfirkan kelompok yang di luar golongannya. ${ }^{1}$ Fenomena ini berlangsung sejak masa klasik hingga kontemporer ini. Di Indonesia misalnya, umat Islam terbagi kedalam kelompok-kelompok organisasi masyarakat. Kelompok-kelompok itu berbeda-beda secara pemikiran maupun gerakan keislaman. Ada yang tradisionalis, reformis, revivalis, dan politis. Terkadang terjadi gesekan sosial antara kelompok itu karena masing-masing punya cara pandang yang berbeda dalam memahami keislaman maupun keindonesian. ${ }^{2}$

Fenomena pengelompokan umat Islam ini menjadi perhatian serius setelah terjadi aksi-aksi kekerasan atas nama agama. Dalam setiap kekerasan yang terjadi selalu muncul streotipikal public akan pemahaman mereka terhadap jenis kelompok yang dimaksud, tidak hanya dalam konteks Indonesia tapi secara global. Peristiwa 11 September 2001 di Amerika Serikat yang menghancurkan gedung WTC dan Pentagon menjadi momentum awal bagi munculnya steriotipikal dunia terhadap kekerasan yang dikait-kaitkan dengan agama. Aksi terornya disebut terorisme, sementara segala sesuatu yang melatar belakanginya disebut dengan istilah radikalisme dan radikalisme dikait-kaitan dengan agama, khususnya Islam. Maka Islam menjadi pusat perhatian. Siapa kelompok umat Islam yang dianggap berpotensi radikal.

Sebagai implikasinya, opini radikalisme agama berkembang secara liar di kalangan masyarakat. Apalagi pemerintah RI secara terbuka menyatakan perlawanan terhadap radikalisme agama atas dasar keamanan dan mencegah terorisme. Muncul sikap kecurigaan sekaligus kekhawatiran terhadap aksi dan kegiatan keagamaan yang ditenggarai dapat merongrong keutuhan negara yang sudah berjalan mapan. Pesantren sebagai pusat lembaga pendidikan Islam tak luput dari kecurigaan ini. Muncul opini bahwa pondok pesantren adalah sarangnya Islam radikal. Meski opini tersebut bersifat kemungkinan, namun kecurigaan adanya Islam radikal itu tetap muncul, meski tidak bisa disama ratakan pada semua pondok pesantren. Sebab pondok pesantren itu, baik antara yang satu dengan yang lainnnya berbeda-beda. ${ }^{3}$ Sebagian kelompok umat Islam pun menjadi sasaran dari term ini.

Term radikalisme yang berkembang secara liar di tengah masyarakat melahirkan dugaan yang variatif. Radikalisme agama dapat dipahami sebagai sebuah paham atau gerakan ekstrim yang dapat merusak keharmonisan hidup berbangsa dan bernegara dengan pemahaman-pemahan yang literal terhadap agama. Atau radikalisme dapat menjadi alat propaganda untuk mendiskreditkan

\footnotetext{
${ }^{1}$ Harun Nasution,Teologi Islam, Sejarah Analisa Perbandingan, ( Jakarta : UI-Press, 1986) Cetakan 2012, 8-11

${ }^{2}$ Moh Wardi. Kontribusi Pemikiran Moh. Mahfud MD Konfigurasi Politik dalam Merespon Dinamika Keislaman dan Kebangsaan. In: Proceedings of Annual Conference for Muslim Scholars. 2018. p. 134143.

${ }^{3}$ Edi Susanto. Kemungkinan Munculnya Paham Islam Radikal Di Pondok Pesantren. Tadris, Volume 2 No 12007$), 14$
} 
kelompok-kelompok tertentu. Sehingga dengan demikian, membicarakan radikalisme agama dapat mengandung term krusial dan sensitif yang berpotensi konflik secara horizontal. Perlu mencari persepsi bersama atau penafsiranpenafsiran yang mendekatkan persepsi yang berbeda. Pandangan ini perlu dicari dari ormas-ormasIslam itu sendiri yang berbeda dalam pemikiran atau pun gerakan. Sebab belum ada kesepakatan terminologis dari para ahli tentang term ini. Beberapa pemikir menyebut dengan istilah yang berbeda dibandingkan dengan radikalisme agama, antara lain neo khawarij, ${ }^{4}$ khawarij abad 20,5 dan fundamentalisme. Fadzlurrahman menyebutnya dengan istilah neo-revivalisme atau neofundamentalisme. Al-Jabiri dan Gilles Kipel menyebut dengan istilah ekstrimisme Islam. Al-Fadl ${ }^{6}$ menyebut dengan gerakan Islam puritan. ${ }^{7}$

\section{Metode Penelitian}

Penelitian ini adalah kualitatif dengan objek lokasi adalah kabupaten Pamekasan yang difokuskan pada ormas ormas Islam lokal yang ada di Pamekasan. Data-data yang ingin dihasilkan adalah data deskriptif yang diperoleh dari data-data berupa tulisan dan kata-kata yang berisi dari sumber atau informan yang dapat diteliti dan dipercaya.

Sumber data dalam penelitian ini terdiri dari sumber primer dan sekunder. Sumber primer yang digunakan adalah responden, yaitu orang yang merespon atau menjawab pertanyaan peneliti, baik pertanyaan tertulis maupun lisan. Responden dalam penelitian ini secara sampel diambil dari refresentasi ormas-ormas Islam di Pamekasan tentang bagaimana sikap mereka terhadap term radikalisme agama.Ada pun data sekundernya diambil dari telaah kepustakaan (library research). Penelitian ini akan mencari bahan-bahan yang punya relevansi dengan radikalisme agama, baik buku, jurnal ilmiah dan lain sebagainya.Data-data dikumpulkan dalam penelitian ini dengan menggunakan teknik wawancara, baim terstruktur atau pun tak terstruktur. Data-data kemudian dianalisis menggunakan teori hermeneutika.

\section{Pembahasan \\ Keberadaan Ormas Islam di Pamekasan}

Kabupaten Pamekasan memiliki potensi yang sangat besar dalam aspek keagamaan. Berdasarkan pusat statistik kabupaten Pamekasan yang update terakhir 25 Juni 2020, mayoritas penduduk kabupaten Pamekasan beragama Islam dengan persentase $99 \%$ lebih, yaitu 842.215, sementara pemeluk Protestan berjumlah 496, Katolik 482, Hindhu 23, dan Budha 56 orang. ${ }^{8}$ Tempat-tempat ibadah yang berupa masjid sebanyak 1.166, Mushalla sebanyak 4.685, Greja

\footnotetext{
4 M.A. Shaban. Islamic History. (Cambridge : Cambridge University Pres, 1994), 56

${ }^{5}$ Harun Nasution. Islam Rasional. (Bandung : Mizan, 1995), 125

6 Moh Wardi. "Hermeneutika Khaled Abou El Fadl; Sebuah Kontribusi Pemikiran Dalam Studi Islam." Al-Ulum: Jurnal Pemikiran Dan Penelitian Ke Islaman 1.1 (2014).

7 Dede Rodin. Islam dan radikalisme, Tela'ah ayat-ayat kekerasan dalam al-Qur'an. Addin, Volume 10 No 1, februari 2016, 33

8https://Pamekasankab.bps.go.id/statictable/2020/06/25/315/banyaknya-pemeluk-agamamenurut-kecamatan-2019-jiwa-.html, diakses pada 6 September 2020
} 
sebanyak 6, sementara Pura dan Vihara masing-masing satu. ${ }^{9}$ Selain data tersebut, ada Ormas-ormas Islam yang cukup banyak di Pamekasan, antara lain adalah, NU, Muhammadiyah, al-Irsyad, Persis (Persatuan Islam), SI (Syarikat Islam), dan Hidayatullah. Ormas-ormas itu membentuk wadah komunikasi yang disebut dengan Forum Komunikasi Ormas Islam (Fokus).

Keberadaan Fokus di kabupaten Pamekasan adalah sebagai wadah silaturahmi bertemunya ormas-ormas Islam di Pamekasan. Fokus didirikan pada 29 September 2003 di Pamekasan yang diawali oleh pertemuan lima pimpinan ormas Islam di Pamekasan, yaitu NU, Muhammadiyah, SI, PERSIS, dan Al-Irsyad. Pertemuan lima Ormas itu sepakat membentuk wadah komunikasi yang disebut sebagai Fokus sekaligus menjadi anggotanya, lalu ditambahkan lagi satu ormas yang masuk sebagai anggota, yaitu Hidayatullah. Kecuali FPI yang tidak masuk fokus. ${ }^{10}$ Berdirinya fokus bertujuan menyatukan visi dan misi antar ormas Islam dalam mendukung terwujudnya izzul Islam wal muslimin dan sebagai wadah silaturahmi ormas-ormas Islam di Pamekasan dalam mengatasi problem-problem keumatan. Semua yang ada dalam forum ini sepakat mengedepankan persamaan-persamaan dan tidak menonjolkan perbedaan-perbedaan,

Selain dari organisasi yang sudah dikenal itu, di Pamekasan terdapat organisasi yang bernama Aliansi Ulama Madura (AUMA) dan Lembaga Pengkajian dan Penerapan Syari'at Islam (LP2SI) di samping Majelis Ulama Indonesia (MUI) Kabupaten Pamekasan. Berdasarkan namanya, AUMA merupakan semacam asosiasi ulama atau kiyai Madura karena jajaran pengurusnya terdiri dari perwakilan kiyai dan ulama dari semua kabupaten di Madura. Namun kantor Pusat AUMA Ini ada di Kabupaten Pamekasan. Di dalamnya terdiri dari para ulama dari bermacam elemen, mulai dari yang berbasis pesantren sampai yang berafiliasi dengan ormas-ormas yang sudah disebutkan. ${ }^{11}$

Lembaga Pengkajian dan Penerapan Syari'at Islam (LP2SI) merupakan organisasi yang dibentuk oleh pemerintah kabupaten Pamekasan. Elemen pengurusnya sebenarnya juga terdiri dari ormas-ormas Islam yang sudah dikenal, namun organisasi ini difokuskan untuk merumuskan konsep dan implementasi mewujudkan tatanan masyarakat Islami yang konsepnya diberi nama (Gerakan pembangunan Masyarakat Islami). Target utama LP2SI adalah mencakup lima hal, yaitu membangun keluarga Islami, pendidikan Islami, kondisi sosial budaya yang Islami, dan aparatur pemerintahan yang Islami. Jadi berbeda dengan ormas lain yang menyikapi persoalan keumatan dan kebangsaan, LP2SI lebih mengarah pada bagaimana menciptakan nilai-nilai yang Islami pada lima targetnya tersebut. ${ }^{12}$

Dengan gambaran tersebut maka objek penelitian ini diambil dari ormasormas yang mempunyai karakter, kultur gerakan, dan pemikiran tersendiri seperti NU, Muhammadiyah, SI, PERSIS, Al-Irsyad, Hidayatullah, dan FPI. Bentuk gerakan

\footnotetext{
${ }^{9}$ https://Pamekasankab.bps.go.id/statictable/2020/06/25/318/banyaknya-tempat-ibadahmenurut-jenisnya-per-kecamatan-2019-unit-.html, diakses pada 6 September 2020 10 Nor Hasan. Kerukunan Intern Umat Beragama di Kota Gerbang Salam, Melacak Peran Forum Komunikasi Ormas Islam (Fokus) Pamekasan. Nuansa, Volume 12, No 2 Juli-Desember 2015, 415 11 Abd A'la, Ahwan Mukarram, Mukhammad Zamzami. Kontribusi Aliansi Ulama Madura (AUMA) dalam Merespon Isu Keumatan dan Kebangsaan di Pamekasan Madura. Religio, Jurnal Studi AgamaAgama, Volume 8 No 2, 2018, 233-235

12 LP2SI Pamekasan. Mengenal Gerbang Salam. (LP2SI Pamekasan, 2011), 1-5
} 
dan pemikiran organisasi yang berbeda tersebut tentu akan mewarnai pandangan terhadap apa yang disebut radikalisme agama. Sementara AUMA, LP2SI, dan MUI sudah mencakup elemen-elemen ormas tersebut

\section{Sikap Terhadap Radikalisme Agama}

Menurut psikologi sosial, sikap didefinisikan sebagai evaluasi positif atau negatif dari reaksi terhadap objek, orang, situasi atau aspek lain dan memungkinkan kita untuk memprediksi dan mengubah perilaku masyarakat. ${ }^{13}$ Eagly dan Chaiken membagi dua model definisi sikap. Pertama, sikap sebagai kombinasi kognitif, afektif dan konasi. Kedua, sebagai penilaian positif atau negatif terhadap suatu objek tertentu yang diekspresikan dengan intensitas tertentu. ${ }^{14}$ Jadi sikap mencerminkan perasaan atau penilaian individu terhadap suatu objek. Walaupun objeknya sama, namun sikap setiap orang terhadap objek belum tentu sama. Sebab keadaan setiap orang berbeda-beda bisa karena pengaruh keadaan individu, pengalaman, lingkungan, dan hal lain yang melatar belakanginya.

Berdasarkan definisi tersebut, maka sikap dapat dipahami dalam tiga struktur. Struktur pembentukan sikap memang terdiri tiga komponen, yaitu kognitif, afektif, dan konatif. ${ }^{15}$ Komponen kognitif terdiri dari persepsi, kepercayaan, atau steriotipe yang dimiliki individu tentang sesuatu. Persepsi atau kepercayaan bisa berwujud pandangan atau sesuatu yang telah terpolakan dalam fikirannya. Komponen afektif melibatkan emosional. Reaksi emosional terhadap suatu objek dapat membentuk sikap positif atau negatif, baik tidak baik, bermanfaat atau tidak bermanfaat tergantung kepercayaannya terhadap objek. Sementara komponen konatif berkaitan dengan kecenderungan tindakan seseorang terhadap objek tersebut. ${ }^{16}$

\section{Sikap kognitif ormas Islam}

Radikalisme agama dipahami sebagai cara-cara beragama yang sama sekali tidak menampilkan wajah Islamsebagai rahmatan lil alamin. Substansi dari radikalisme agama jika mengamati dari definisi yang berkembang terakhir, menampilkan jalan kekerasan, sementara Islamrahmatan lil alamin menampilkan Islam dengan pendekatan yang benar. Dua hal ini seringkali dipahami secara kontradiktif. Sehingga muncul asumsi bahwa penindakan terhadap kemaksiatan sebagai tindakan radikal dan sebaliknya pembiarannya dianggap rahmatan lil alamien. Padahal bagi beberapa kelompok, penindakan terhadap kemaksiatan merupakan bentuk konsistensi pada ajaran agama. Dalam konteks seperti ini, makna radikalisme agama bias dan mengarah pada konsistensi seseorang dalam menjalakan agamanya. Sedangkan rahmatan lil alamin bisa dipelintir sebagai sikap pembiaran terhadap kemunkaran. Jadi pandangan liar tersebut bisa mewarnai narasi-narasi opini publik. Lalu bagaimana pandangan ormas Islam?

\footnotetext{
${ }^{13}$ Tyas Palupi, Dian Ratna Sawitri. Hubungan Antara Sikap Dengan Perilaku Pro-Lingkungan Ditinjau dari Perspektif Theory off Planned Behavior. Proceeding Biology Edication Comprence, Volume 14 No $1,2017,215$

${ }^{14}$ Tyas Palupi, Dian Ratna Sawitri. Hubungan Antara Sikap Dengan Perilaku Pro-Lingkungan Ditinjau dari Perspektif Theory off Planned Behavior. Proceeding Biology Edication Comprence, Volume 14 No 1, 2017, 215

${ }^{15}$ Saifuddin Azwar. Sikap Manusia. (Yogyakarta : Liberty, 1988), 17-18

16 Damiyati Zuchdi. Pembentukan Sikap. Cakrawala Pendidikan, No 3 tahun XIV November 1995), 53
} 
Pemahaman ormas Islamdi PamekasanIslamterhadap rahmatan lil alamin sebenarnya tidak jauh berbeda antara yang satu dengan yang lain. Substansinya, Islamdipahami sebagai agama yang mencintai kedamaian terhadap semua makhluk, baik pada manusia maupun binatang sebagaimana cara-cara yang diajarkan oleh Nabi Muhammad Saw. Islam adalah agama yang mengayomi, peduli dan melindungi hak-hak manusia. Ada yang memahaminya sebagai agama yang kaffah, yang menyentuh semua aspek kehidupan manusia.

Para informan memperlihatkan pandangan yang serupa tentang Islamrahmatan lil alamien dengan penekanan masing-masing. Ada yang lebih menekankan pada pola pendekatannya yang khas, ada yang menekankan pada konten ajaran Islamyang universal, ada yang menekankan dengan pandangan politis, ada yang menekankan sikap perlindungan dan kasih sayang, dan ada yang menekankan pelaksanaan Islam yang kaffah. Intensitas pandangan mereka ini terlihat sekali dipengaruhi oleh latar belakang organisasi keagamaan masingmasing.

Meski demikian, ormas-ormas Islam di Pamekasan memberikan pandangan yang berbeda-beda dalam menyikapi apa yang disebut radikalisme agama. Sebagian besar mereka memberikan definisi secara jelas, ada yang mendefinisikan dengan tidak jelas, dan ada yang tidak mau mendefinisikan. Berikut presentasenya:

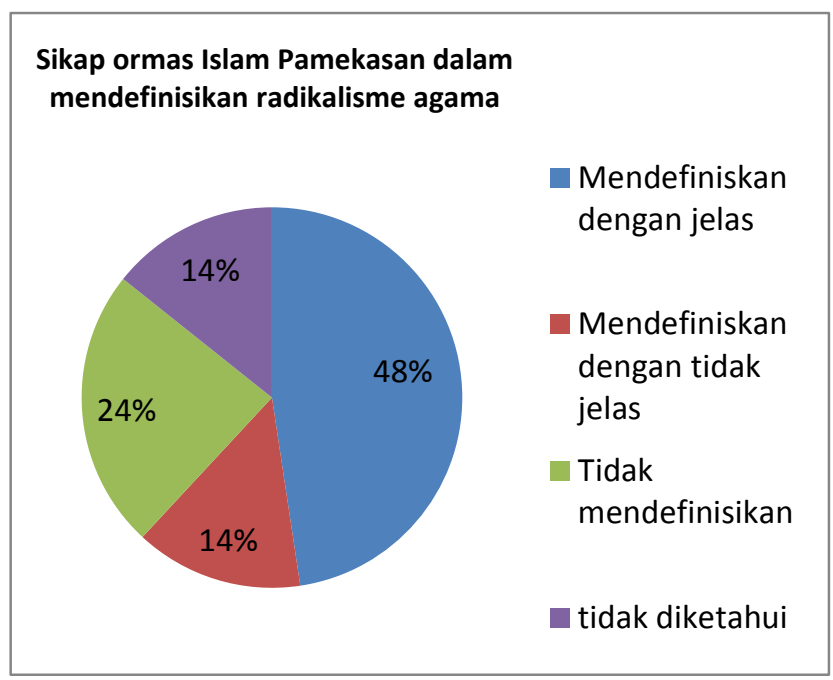

Grafik 1: Sikap Ormas dalam mendefinisikan radikalisme agama

Persentase ormas yang mendefinisikan radikalisme agama jauh lebih besar dari pada yang tidak jelas mendefinisikan atau yang tidak mendefinisikan. Perbedaan pandangan ormas IslamPamekasan terhadap radikalisme agama dapat dilihat dari yang mendefinisikan secara jelas.

Bagi yang memberikan definisi, maka radikalisme agama dikonsepsikan dengan adanya unsur kekerasan, pemaksaan, penyimpangan berfikir dan berlebihan dalam beragama. Berfikir diluar konteks yang sebenarnya akan terwujud dalam bentuk perilaku yang tidak nyaman. Bisa berupa bentuk intoleransi dalam aspek sosial dan keagamaan. Atau sering mengambil jalan kekerasan dalam perilaku keagamaan. Hal-hal yang seharusnya tidak perlu mengambil jalan kekerasan, tapi mengambil jalan kekerasan. Sehingga cara-caranya dapat dipahami 
sebagai sikap berlebihan dalam beragama. Sesuai definisi terakhir di atas, ghuluw fi ddin dapat berupa klaim menyalahkan orang lain yang seharusnya tidak perlu dipersalahkan jika hanya berbeda dalam hal yang tidak mendasar, atauberupa tindakan yang menyimpang dari tempat yang sebenarnya.

Definisi yang diberikan mengarah pada objek pengertian yang sama, yaitu penyimpangan dari ajaran agama. Jenis penyimpangan agama yang dimaksud adalah ghuluw fi ddin, sikap berlebihan dalam beragama, baik dalam konteks berfikir dan berperilaku. Pelakunya mungkin tidak bermaksud ingin menyesatkan agama,tapi caranya dalam beragama yang tidak benar. Dalam konteks berfikir bisa berbentuk pemikiran yang tidak sesuai konteksnya sehingga seringkali menyalahkan orang lain yang berbeda pendapat, bahkan sampai mengkafirkan. Sedangkan dalam konteks perilaku bisa menjalankan agama dengan cara-cara kekerasan. Wujud konkritnya ada yang radikal dalam pemikiran, ada yang radikal dalam perilaku, ada yang radikal dalam pemikiran sampai pada perilaku. Contoh radikal dalam pemikiran seperti tidak menghargai kelompok lain, merasa kelompoknya paling benar, dia menggunakan ayat-ayat yang menurut dia dan tidak menggunakan kelompok lain ${ }^{17}$ Menyuarakan jihad di negri damai itu termasuk dari pemikiran radikal. Atau sistem yang ada di pemerintah karena tidak semuanya sesuai dengan hukum Islam lalu dianggap dengan hukum toghut itu bagian dari pemikiran radikal. Hal-hal seperti itu bukan dari ajaran Islam karena itu pendapat oknum. ${ }^{18}$ Kelompok yang bermanhaj aswaja tetapi mereka kemudian menyelewengkan konsep aswaja itu sendiri bisa dianggap radikal."19

Ada pun contoh yang radikal dalam perilaku atau tindakan seperti yang memaksakan. Bom bunuh diri atas nama agama. ${ }^{20}$ Ada yang dari pemikiran sampai menjurus ke tindakan seperti contoh orang lain dianggap salah dan harus mati. Seperti ada orang asing dan umat Islam bersama mereka dianggap sama misalnya. ${ }^{21}$ Mengkafirkan orang, intoleransi. Sempit pemahaman tentang Islam, atau salah pemahaman tentang Islam. Jadi mengarah juga pada sikap berlebihan dalam agama. Seperti Abdurahman bin Muljam yang sampai melakukan kasus teror pembunuhan. ${ }^{22}$. Atau Seperti dalam PIKADA Jakarta, orang yang menolak Ahok sampai tidak mau menshalatkan jenazah orang Islam yang beda pilihan dalam konteks politik. Jadi ciri-cirinya intoleran atau gampang mengkafirkan atau menyesatkan. ${ }^{23}$

Lebih lanjut dapat dikatakan bahwa radikalisme memiliki pemahaman yang objektif dan subjektif. Objektif jika pemahamannya sejalan dengan makna asalnya, dan subjektif jika tergantung pada penilaian orang-orang yang memahaminya. ${ }^{24}$ Maka ada kecenderungan pengkaburan dalam pemahaman radikalisme agama. Pengkaburan itu mengarah pada stigma terhadap penganut agama (Islam) secara

\footnotetext{
17 Moh. Subhan. (NU). Wawancara pada tanggal 09-07-2020

18 Ikrom (PERSIS). Wawancara pada tanggal 04-08-2020

19 Umar Hamdan Karrar. (FPI) Pada tanggal 19-07-2020

${ }^{20}$ Herman Sucipto (al-Irsyad). Wawancara pada tanggal 18-08-2020

21 Qudus (PERSIS) Wawancara pada tanggal 30-07-2020

${ }^{22}$ Hendri Masduki (Muhammadiyah). Wawancara pada tanggal 08-07-2020

23 Taufik Hasyim (NU). Wawancara pada tanggal 05-07-2020

24 Abdul Ghaffar Muzakki (NU). Wawancara pada tanggal 20-07-2020
} 
luas. ${ }^{25}$ Suatu stigma yang tentu tidak menguntungkan bagi pihak-pihak yang menerimanya.

Beberapa informan dari ormas Islam di Pamekasan lebih suka tidak mendefinisikan radikalisme agama. Mereka menyampaikan pandangannya bahwa dalam Islam kita tidak mengenal radikal itu.Yang dimaksud radikalisme siapa dan apa. Karena itu muncul dari musuh-musuh Islam. yang ada dalam Islam adalah Islam kaffah. Kata radikalisme ini susah diartikan karena tergantung dari siapa yang membawanya. Jadi dalam Islam tidak ada terminologinya. Terminologinya tidak jelas. ${ }^{26}$ Radikalisme itu tidak ada, itu hanya persolaan politik. Karena itu adalah istilah bagi umat Islam yang menjalankan ajarannya secara kaffah. Jadi radikalisme itu adalah tuduhan orang yang tidak memahami agama yang melihat adanya perilaku yang dianggapnya intoleran sebagai sebuah tindakan radikal. Secara politik, radikalisme muncul dari sebuah ketakutan bagi sebuah kepentingan yang merasa terancam jika Islam dilaksanakan secara kaffah. ${ }^{27}$

Pandangan tersebut memperlihatkan kecurigaan terhadap adanya kepentingan dari kelompok lain yang merasa dirugikan dengan pelaksanaan ajaran Islam sehingga muncul istilah radikalisme agama. Jadi radikalisme agama dipahami dengan pendekatan politis. Dalam hal ini bukan berarti pemikiran atau perbuatan menyimpang dalam beragama dianggap tidak ada, akan tetapi hanya tidak setuju dengan istilah radikalisme agama yang dikait-kaitkan dengan Islam. Karena radikal itu ada dimana-mana tidak hanya menyangkut orang Islam itu sendiri. Personalnya tidak hanya Islam. ${ }^{28}$ Apalagi terminologinya dipandang tidak jelas.

Jadi adanya objek pemikiran atau perilaku yang menyimpang itu diakui, namun bisa karena pemahaman agama yang salah atau karena ketidak adilan. Sehingga kemunculannya bisa ada dimana-dimana tidak selalu berkaitan dengan agama. Sehingga penggunaan istilah radikalisme agama dianggap tidak tepat. Dan bahkan dipandang berbau politis seperti terhadap individu atau kelompok yang dianggap mengancam kepentingan maka tuduhan seperti itu dimunculkan. Dalam konteks Indonesia maka terkadang dibuat-buat sesuatu untuk membuat kesan bahwa Umat Islam Radikal. Contohnya komando jihad di zaman Soeharto. Komando jihad itu bukan semacam syi'ar gerakan Islam. tapi dibuat kelompok lain agar membuat kesan bahwa Islam itu memang radikal sebagaimana yang dituduhkan. Komando jihad dibuat mau mendirikan negara Islammisalnya atau membunuh orang nasrani misalnya. Jadi memang dibuat seperti ISIS kalau secara internasional. ${ }^{29}$ Contoh lagi pada masa Masyumi sekitar tahun 50-an, Moh. Nasirsebagai tokoh Masyumi itu dikatakan radikal karena tidak mau menerima Nasakom. Syarikat Islam (SI) dulu juga pernah dicap radikal. Pada waktu itu ada rencana pemerintah untuk Indonesia bekerja sama dengan Cina. ${ }^{30}$

Ada yang kurang jelas dalam memberikan definisi karena hanya memberikan pengelompokan terhadap umat Islam, yaitu kelompok yang ingin menerapkan Islamdalam kehidupannya, dan kelompok ini yang memperjuangkan Islam. Kedua

\footnotetext{
25Umar Hamdan Karrar. (FPI) Pada tanggal 19-07-2020

26 Daeng Ali Taufik. (Muhammadiyah). wawancara pada tanggal 04-07-2020

27 Sayuri (Syarekat Islam). Wawancara pada tanggal 04-07-2020

28 Daeng Ali Taufik. (Muhammadiyah). wawancara pada tanggal 04-07-2020

${ }^{29}$ Sayuri (Syarekat Islam). Wawancara pada tanggal 04-07-2020

30 Syadili. (Syarekat Islam). Wawancara pada tanggal 04-08-2020
} 
adalah kelompok oportunis, yaitu cari aman. Artinya kalau kelompok pertama punya pengaruh maka dia akan ikut kelompok itu, tapi jika dirasa menyulitkan dia maka dia mundur atau cari aman. Ketiga adalah kelompok munafik, ini umat Islamyang menusuk dari dalam. Tampilannya adalah Islam. dia ngomong Islamtapi dia nusuk dari dalam. Keempat, adalah kelompok Islamliberal. Mereka ingin alQur'an mengikuti konteks zaman. Jadi posisi radikalisme dipertanyakan. Karena tak ada radikalisme dalam Islam. Radikalisme itu adalah sesuatu yang ngaur, yang ekstrem. Untuk mempengaruhi dan sebagainya dia melakukan tindakan-tindakan yang anarkis. Jadi memakai cara-cara kotor yang tidak dibenarkan dalam Islam. ${ }^{31}$

Pandangan demikian tampak abstrak. Sebab objek yang dikonsepsikan tidak jelas. Tapi esensinya dipahami dalam makna yang negatif. Jika dikaitkan dengan definisi-definisi yang lain sebelumnya dapat dipahami dalam arti kekerasan atau cara-cara kotor yang tidak bisa dibenarkan dalam ajaran Islam.

Meski berbeda pandangan tentang istilah radikalisme agama, namun semua ormas Islamtidak menepis adanya pemeluk agama yang tidak benar, berlebihan atau menyimpang dalam menjalankan agamanya. Kasus seperti itu sudah ada dalam sejarah Islam klasik, khususnya pandangan keagamaan kelompok Khawarij yang sempit dan dangkal sampai menggiring mereka pada cara-cara tindakan beragama dengan kekerasan. Lebih dari itu, semua ormas Islam di Pamekasan sepakat bahwa Islambukan agama yang radikal.

Jika radikalisme agama dipahami sebagai bentuk penyimpangan dalam beragama makadarimana faktor radikalisme agama tersebut. Ada yang bependapat bahwa faktornya adalah salah dalam memahami teks dan mereka ghulul atau berlebihan dalam Islam, ${ }^{32}$ bisa karena kepentingan. Misal kepentingan kelompok tertentu agar memprofokasi masyarakat Indonesia."33bisa karena ketidak adilan, bisa secara politik adanya radikalisme muncul dari sebuah ketakutan bagi sebuah kepentingan yang merasa terancam jika Islam dilaksanakan secara kaffah. ${ }^{34}$ Bisa dikarenakan inhiraf anil manhaj al-jadah, yaitu penyelewengan dari jalan yang sudah lurus yang sudah dijalan para sahabat. ${ }^{35}$

Dengan demikian faktor radikalisme agama itu beragam berdasarkan pandangan ormas Islamdi Pamekasan, yaitu:1) Memahami sumber agama secara tidak kompleks, 2). Salah dalam memahami sumber agama, 3). Berlebihan dalam menjalankan agamanya. 4). Kapasisitas keilmuan atau pengalaman yang kurang, 5). Pandangan yang menyimpang,6). Politik, dan 7). Pendidikan.

\section{Sikap afektif dan konasi ormas Islam}

Ormas-ormas Islam di Pamekasan juga mengambil reakasi emosional yang beragam dalam menilai apakah persoalan radikalisme agama secara real ada ada atau hanya sekedar isu. Hasil data lapangan menjelaskan sebagaiberikut:

\footnotetext{
31 Herman Sucipto (al-Irsyad). Wawancara pada tanggal 18-08-2020

32 Taufik Hasyim (NU). Wawancara pada tanggal 05-07-2020

33 Abdurrahman Abbas (NU). Wawancara pada tanggal 10-07-2020

${ }^{34}$ Sayuri (Syarekat Islam). Wawancara pada tanggal 04-07-2020

35 Umar Hamdan Karrar. (FPI) Pada tanggal 19-07-2020
} 


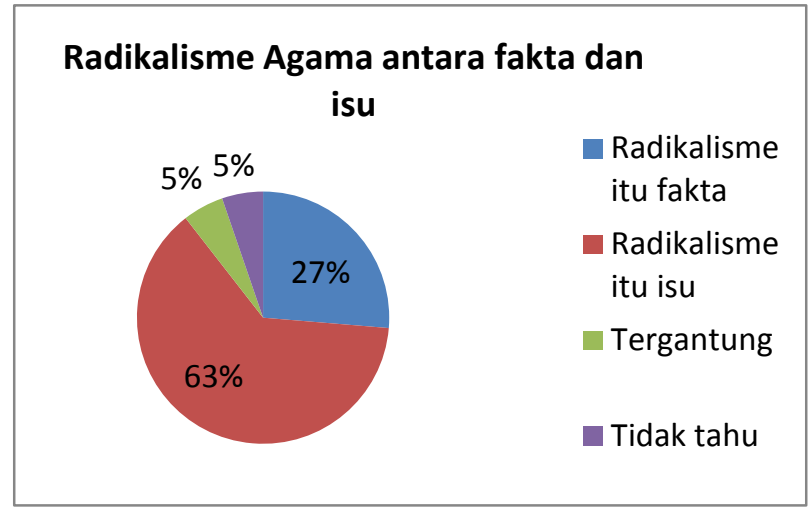

Grafik 2: penilaian ormas IslamPamekasan

terhadap radikalisme agamaantara fakta dan isu.

Berdasarkan data tersebut, sebagian besar ormas menyatakan bahwa persoalan radikalisme agama itu isu. Kondisi tersebut berbalik ketika sebagian besar mereka menjelaskan definisinya. Mereka menganggap radikalisme itu sebagai isu untuk melakukan cuci otak dan stigma menyudutkan Islam di mata dunia sehingga muncul Islamofobia dimana-mana. Isu itu diciptakan karena Islam selalu dianggap penghalang bagi kepentingan peradaban Barat dengan kapitalismenya.

Jadi dalama pandangan kebanyakan ormas islam di Pamekasan bahawa radikalisme itu isu dan stigma yang dibuat-dibuat. ${ }^{36}$ Radikalisme itu adalah isu yang mempengaruhi publik dan mencuci otak genarasi Islamyang dangkal dalam akidah agama. ${ }^{37}$ Kalau ditujukan pada Islam itu adalah penyematan atau stigma terhadap Islam untuk menyudutkan Islam dalam kancah internasional. ${ }^{38}$ Radikalisme itu isu yang dihubungkan dengan fakta. Sudah diketahui faktanya bahwa Islam itu tidak senang dengan kapitalisme sehingga dibuatlah isu radikalisme. ${ }^{39}$

Bagi yang menyatakaan real maka sesuai dengan apayang mereka definisikan. Radikalisme dipahami sebagai perilaku menyimpang dalam beragama. Tentu perilaku seperti itu ada dalam penganut agama. Namun jumlahnya tidak banyak. ${ }^{40}$ Ada yang menilai radikalisme sebagai fakta yang berbeda. Bahwa radikalisme diakui ada tapi tidak bisa dipakai untuk melabeli perilaku yang menyimpang dari kelompok umat Islam.karena radikalisme dianggap ada dalam semua elemen agama dan golongan. Juga bisa berupa perilaku yang mengambil cara-cara kekerasan dalam berbagai persoalan. ${ }^{41}$ Ada yang berpandangan bahwa radikalisme yang dipahami sebagai sebuah penyimpangan perilaku keagamaan itu real. Namun itu bisa dianggap sebagai isu jika digeneralisasikan untuk semua umat Islam. ${ }^{42}$ Maka konsepsinya harus jelas sehingga bisa disimpulkan. ${ }^{43}$

\footnotetext{
${ }^{36}$ Herman Sucipto (al-Irsyad). Wawancara pada tanggal 18-08-2020

37 Umar Hamdan Karrar. (FPI) Pada tanggal 19-07-2020

38 Hendri Masduki. (Muhammadiyah) wawancara pada tanggal 08-07-2020

39 Sayuri (Syarekat Islam). Wawancara pada tanggal 04-07-2020

40 Qudus (PERSIS) Wawancara pada tanggal 30-07-2020

${ }^{41}$ Daeng Ali Taufik. (Muhammadiyah). wawancara pada tanggal 04-07-2020

42 Ikrom (PERSIS). Wawancara pada tanggal 04-08-2020

43 Abdul Ghaffar Muzakki (NU). Wawancara pada tanggal 20-07-2020
} 
Meski pun banyak yang menilai radikalisme itu isu dan sebagian menilai real, namun hampir semua anggota ormas Islam itu tidak setuju dengan label Islam radikal itu. Label seperti itu dinilai tidak objektif karena hanya isu dan pembodohan publik. ${ }^{44}$ Radikalisme tidak bisa dilabelkan pada Islam karena pandangan publik bisa mengarah pada penganut agama atau kelompok tertentuk dalam agama. Radikalisme bisa ada dalam semua kelompok keagamaan, bahkan sampai pada yang paling moderat sekali pun, kecuali Al-Qaida yang memang jelas secara kelembagaan. ${ }^{45}$ Islam radikal dinilai sebagai stigma untuk kepentingan politik. ${ }^{46}$

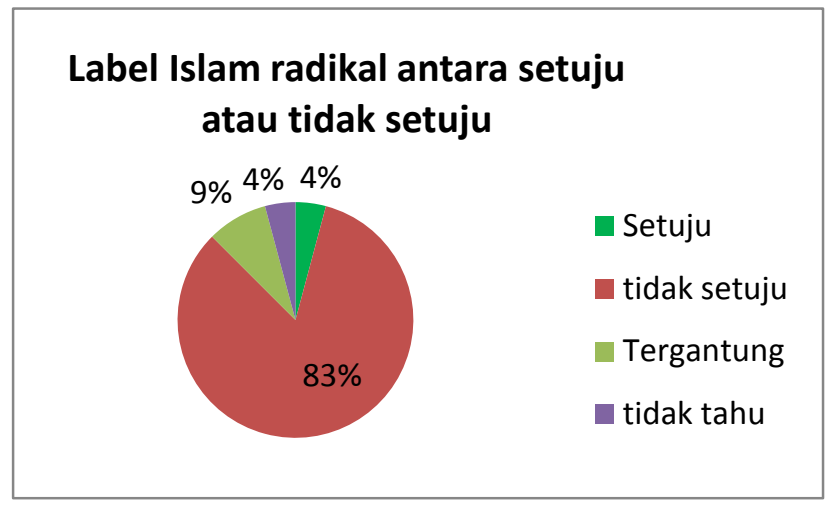

Grafik 3 : Setuju atau tidak setuju terhadap label Islam radikal

Jika dipahami lagi maka secara mendasar semua ormas Islam di Pamekasan tidak setuju dengan label Islam radikal karena pada berdampak pada citra negatif.Bagi semua ormas Islam di Pamekasan radikalisme jelas dirasakan tidak menguntungkan.Citra Islammenjadi negatif dengan radikalisme. Ormas Islamdi di Pamekasanmenyatakan diri punya peran dalam menghadapi persoalan itu, meski intensitas perannya berbeda. Intensitas peran mereka dapat dipahami, baik secara verbal maupun non verbal.

Dalam konteksnon verbal ini adalah seperti Muhammadiyah yang berpandangan ikut mengambil peran dalam mengikis radikalisme (sebagaimana yang dipahami secara negatif) melalui gerakan dakwah dan pendidikan. ${ }^{47}$ Selain itu, ada Persis dan Al-irsyad dalam peran yang serupa, yaitu dakwah Islamiyah dengan bermacam cara dan mendirikan sekolah-sekolah. Ada FPI dengan dakwah sosialnya. Jadi peran non verbal ini berwujud dalam kegiatan keagamaan dan pendidikan. Maka secara non verbal dapat dinyatakan semua ormas Islam di Pamekasansudah ikut serta dalam megambil bagian ini.

Syarikat Islam (SI) juga mengaku ikut mengambil peran dalam menghadapi radikalisme meski secara pasif. SI merupakan organisasi yang memiliki latar

\footnotetext{
${ }^{44}$ Sangat tidak suka karena bertentangan dengan kenyataan. Herman Sucipto (al-Irsyad). Wawancara pada tanggal 18-08-2020 ;Sangat tidak suka dengan isu Islam radikal, karena itu adalah pembohan masyarakat. Umar Hamdan Karrar. (FPI) Pada tanggal 19-07-2020

${ }^{45}$ Saya tidak setuju dengan itu karena dalam organisasi yang moderat seperti NU bisa ada oknum yang seperti itu. Yang kelembagaan seperti al-kaida. Taufik Hasyim (NU). Wawancara pada tanggal 05-072020.

${ }^{46}$ Tidak setuju karena itu adalah kepentingan politik. Sayuri (Syarekat Islam). Wawancara pada tanggal 04-07-2020

${ }^{47}$ Hendri Masduki. (Muhammadiyah) wawancara pada tanggal 08-07-2020
} 
belakang dalam gerakan politik. Pandangannya terhadap radikalisme sejak awal sudah skeptis dan pendekatannya politis. Sehingga ikut mengambil peran dengan cara fasif. Seperti bertindak pasif saja terhadap persoalan teroris itu sudah mengambil peran. Dalam artian hanya tidak berbicara bahwa teroris itu memang dibuat-buat. Sehingga dalam hal ini juga tidak mengambil sikap. ${ }^{48}$

Berbeda dengan ormas Islam yang lain, NU mengambil peran secara verbal maupun non verbal dalam menghadapi persoalan radikalisme agama. Secara verbal, NU memang menyikapi secara terbuka dalam melawan dan mempersempit radikalisme agama. Sehingga NU dalam semua strukturnya mengambil peran yang sama. Secara non verbal, peran tersebut diwujudkan secara nyata dalam gerakangerakan mereka, di samping juga fokus dalam dakwah sosial dan pendidikan. Hal demikian menunjukkan bahwa NU mengambil peran yang cukup intensif dari pada ormas Islam yang lain, khususnya di Pamekasan. NU ini ada di garda terdepan dalam menangani radikalisme itu meski dicaci-dibuli dianggap tidak Islami. Langkahlangkah NU fokusnya adalah di dakwah, yaitu pengajian-pengajian atau melalui kaderisasi formal ke internal. Kalau ke eskternal itu kerjasama dengan pemerintah. ${ }^{49} \mathrm{NU}$ bersinergi dengan pemerintah. Mulai dari pusat sampai bawah bersama pemerintah berkonsultasi berkordinasi dalam memeperkecil ruang gerak radikalisme." 50

\section{Penutup}

Konsep radikalisme belum ada kesepakatan ahli, maknanya mengalami perkembangan dari makna asal yang berkmakna akar. Dalam konteks ilmu pengetahuan masih digunakan makna asal. Namun dalam konteks politik mengalami pergeseran dan mulai dipahami sebagai kelompok yang menginginkan perubahan baik secara reformatif maupun revolusioner. Dalam perkembangannya dipahami sebagai gerakan ekstrem.

Dalam pandangan ormas Islam lokal di Pamekasan, ada yang memahami radikalisme dalam pengertian yang luas, baik positif dan negatif dan ada yang memahami dalam pengertian sempit. Dalam arti luas radikalisme dipahami sebagai gerakan paham yang menginginkan perubahan secara ekstrem yang dilakukan dengan cara-cara kekerasan dalam konteks sosial, politik, dan agama. Jadi radikalisme ada dalam semua elemen tanpa dapat dikaitkan dengan agama. Istilah radikalisme agama pun tidak ditujukan kepada suatu agama secara khusus, misalnya Islam, namun semua agama. Dalam arti sempitradikalisme dipahami sebagai paham yang menjalankan cara-cara beragama secara tidak benar, baik berlebihan dalam agama atau penyimpangan dalam agama. Dalam arti sempit radikalisme agama seringkali dipahami dengan radikalisme Islam atau ekstremisme Islam.

Mayoritas Anggota ormas Islam di Pamekasan juga menilai Radikalisme sebagai isu kepentingan atau stigma untuk mencitrakan Islam secara negatif. Sebab istilah yang digunakan masih bias dan seringkali disalahgunakan oleh kelompok kepentingan. Namun demikian ada yang menilai bahwa radikalisme itu real. Ada

\footnotetext{
${ }^{48}$ Sayuri (Syarekat Islam). Wawancara pada tanggal 04-07-2020

${ }^{49}$ Taufik Hasyim (NU). Wawancara pada tanggal 05-07-2020

50 Moh. Subhan. (NU). Wawancara pada tanggal 09-07-2020
} 
yang memahami radikalisme itu real untuk kelompok eksrem dalam semua golongan tanpa kaitan dengan agama. Ada yang memahami radikalisme itu realdalam konteks agama sebagai paham orang-orang yang menjalankan agama secara tidak benar, secara sempit, secara berlebihan, atau secara menyimpang seperti yang dipahami dalam sejarah Islam sebagai kelompok Khawarij.

Kemudian semua ormas Islam di Pamekasan tidak suka atau tidak setuju dengan istilah Islam radikal atau radikalisme Islam. Islam itu tidak radikal dan jauh dari cara-cara yang tidak benar sebagaimana yang dipahami dari arti radikalisme itu sendiri. Ajaran-ajaran Islam tidak mengajarkan radikalisme. Radikalisme itu adalah berupa pemikiran atau tindakan yang menyimpang.

Namun semua ormas Islam di Pamekasan merasa mengambil peran dalam menghadapi persoalan radikalisme, baik secara verbal atau non verbal atau secara aktif dan pasif. Secara verbal ada yang langsung secara terbuka menyatakan perlawanan terhadap radikalisme. Secara non verbal, peran itu dinyatakan dalam bentuk dakwah dan pendidikan. Jadi intensitas peran ormas Islam di Pamekasan berbeda-berbeda.

\section{DAFTAR PUSTAKA}

Azwar, Saifuddin. Sikap Manusia. (Yogyakarta: Liberty, 1988)

A'la, Abd, Ahwan Mukarram, Mukhammad Zamzami. Kontribusi Aliansi Ulama Madura (AUMA) dalam Merespon Isu Keumatan dan Kebangsaan di Pamekasan Madura. Religio, Jurnal Studi Agama-Agama, Volume 8 No 2, 2018

Hasan, Nor. Kerukunan Intern Umat Beragama di Kota Gerbang Salam, Melacak Peran Forum Komunikasi Ormas Islam (Fokus) Pamekasan. Nuansa, Volume 12, No 2 Juli-Desember 2015

LP2SI Pamekasan. Mengenal Gerbang Salam. (LP2SI Pamekasan, 2011)

Nasution, Harun. Teologi Islam, Sejarah Analisa Perbandingan, (Jakarta: UI-Press, 1986) Cetakan 2012

Nasution, Harun. Islam Rasional. (Bandung: Mizan, 1995)

Susanto, Edi. Kemungkinan Munculnya Paham Islam Radikal Di Pondok Pesantren. Tadris, Volume 2 No 12007

Shaban, M.A. Islamic History. (Cambridge: Cambridge University Pres, 1994)

Palupi, Tyas, Dian Ratna Sawitri. Hubungan Antara Sikap Dengan Perilaku ProLingkungan Ditinjau dari Perspektif Theory off Planned Behavior. Proceeding Biology Edication Comprence, Volume 14 No 1, 2017

Rodin, Dede. Islam dan radikalisme, Tela'ah ayat-ayat kekerasan dalam al-Qur'an. Addin, Volume 10 No 1, februari 2016

Zuchdi, Damiyati. Pembentukan Sikap. Cakrawala Pendidikan, No 3 tahun XIV November 1995)

Wardi, Moh. "Hermeneutika Khaled Abou El Fadl; Sebuah Kontribusi Pemikiran Dalam Studi Islam." Al-Ulum: Jurnal Pemikiran Dan Penelitian Ke Islaman 1.1 (2014).

Kontribusi Pemikiran Moh. Mahfud MD Konfigurasi Politik dalam Merespon Dinamika Keislaman dan Kebangsaan. In: Proceedings of Annual Conference for Muslim Scholars. 2018. p. 134-143.

Abdul Ghaffar Muzakki (NU). Wawancara pada tanggal 20-07-2020 
Abdurrahman Abbas (NU). Wawancara pada tanggal 10-07-2020

Daeng Ali Taufik. (Muhammadiyah). Wawancara pada tanggal 04-07-2020

Hendri Masduki (Muhammadiyah). Wawancara pada tanggal 08-07-2020

Herman Sucipto (al-Irsyad). Wawancara pada tanggal 18-08-2020

Ikrom (PERSIS). Wawancara pada tanggal 04-08-2020

Moh. Subhan. (NU). Wawancara pada tanggal 09-07-2020

Sayuri (Syarekat Islam). Wawancara pada tanggal 04-07-2020

Syadili. (Syarekat Islam). Wawancara pada tanggal 04-08-2020

Taufik Hasyim (NU). Wawancara pada tanggal 05-07-2020

Umar Hamdan Karrar. (FPI) Pada tanggal 19-07-2020

Qudus (PERSIS) Wawancara pada tanggal 30-07-2020 